Fall 2015

\title{
Americans Attitudes Toward the Political Parties and the Party System
}

Howard J. Gold

Smith College, hgold@smith.edu

Follow this and additional works at: https://scholarworks.smith.edu/gov_facpubs

Part of the American Politics Commons

\section{Recommended Citation}

Gold, Howard J., "Americans Attitudes Toward the Political Parties and the Party System" (2015). Government: Faculty Publications, Smith College, Northampton, MA.

https://scholarworks.smith.edu/gov_facpubs/2 


\title{
The Polls - Trends
}

\section{Americans' Attitudes toward the Political Parties and the Party System}

\author{
Howard J. Gold \\ Department of Government \\ Smith College \\ 10 Prospect St \\ Northampton, MA 01063
}

Howard J. Gold is a professor of government at Smith College, Northampton, MA, USA. The author thanks Donald Baumer, Brent Durbin, Ron Seyb, and the anonymous reviewers for helpful comments and suggestions. *Address correspondence to: Howard J. Gold, Department of Government, Smith College, 10 Prospect Street, Northampton, MA 01063; email: hgold@ smith.edu. 
Gold

\begin{abstract}
Drawing on survey data from ANES, Gallup, Pew, and other polls, this article examines attitudes toward the parties and the party system from 1996 to 2014 . A previous Poll Trends analysis of the parties, through 1995, found antipathy toward the party system but not toward the parties themselves. The data since 1996 demonstrate that extreme discontent now extends beyond the party system to the Republican and Democratic parties. It also finds that Americans have grown more likely to see sharp differences between the major parties, and to perceive both parties as too ideological. As for the party system, Americans express a high degree of ambivalence. On one hand, many believe that the major parties do not do an adequate job of representing the people, and that the country needs a third political party. On the other hand, there is skepticism that a third party would improve the quality of American democracy. Surveys continually register almost no support or even willingness to seriously consider support for a third party candidate.
\end{abstract}


Poll Trends-Americans' Attitudes toward the Political Parties and the Party System

Americans' attitudes toward political parties have changed considerably since the 1950s. The early work on partisanship found that citizens held a deep attachment to political parties; that they interpreted the complex world of politics through the lens of partisanship; and that this profound connection made it unlikely that voters would develop loyalty to a third party (Campbell et al. 1960). Subsequent research, based on trends in the 1970s and 1980s, suggested that rising issue awareness alongside institutional and generational changes contributed to weakening Americans' partisan attachments (Beck 1976; Nie et al. 1976; Polsby 1983). Wattenberg (1998) went even further, maintaining that parties had become increasingly irrelevant, and were supplanted by candidates, in the minds of voters. But as elite-level partisan polarization crystallized in the 1990s and 2000s, several scholars argued that a partisan resurgence, rooted in this deepening polarization, took hold (Abramowitz and Saunders 1998; Hetherington 2001; Green et al. 2002; Stonecash, Brewer, and Mariani 2003; Saunders and Abramowitz 2004; Baumer and Gold 2010). Fiorina et al. (2011) countered that polarization was limited to partisan elites, and that these sharp divisions left a centrist majority with little representation.

In a Poll Trends article that appeared in Public Opinion Quarterly in 1996, Christian Collet (1996) examined perceptions of the parties and the party system. He presented survey data that showed discontent with the two-party system and strong support for a possible third party candidate in presidential elections. Collet's conclusions suggested that antipathy was directed toward the two-party system, and not toward the Democratic and Republican parties, both of which still commanded deep loyalty. He also found that the public wanted more choice at the polls, not necessarily the replacement of 
a major party by a new party. In short, Collet found significant discontent with the twoparty system, but ambivalence about the electoral and governing prospects of a new party.

Collet's article examined partisan polling trends through 1995. It appeared not long after H. Ross Perot ran one of the most successful third-party campaigns in American history, and was on the verge of a second presidential campaign. This article picks up where Collet left off, examining perceptions of the political parties and the party system from 1996 until 2014. There is reason to expect that attitudes toward the parties would have changed since the mid-1990s. The partisan-driven impeachment of President Clinton, two protracted wars, economic downturn, and increasingly vitriolic partisan polarization, especially in Congress, may well have produced not only greater dissatisfaction with the two major parties, but also a heightened receptivity toward a new party competing on the national scene.

The analysis of trends in public opinion toward political parties is divided into three sections. The first examines how assessments of the Democratic and Republican parties changed since the mid-1990s; the second section describes how the public perceives differences between the parties, and the third examines public satisfaction and dissatisfaction with the party system as well as the public's openness to a new national third party.

\section{Assessments of the Major Parties}

Over the years, there has been no shortage of survey questions that ask Americans what they think of the Democratic and Republican parties. This has been asked in many 
Poll Trends-Americans' Attitudes toward the Political Parties and the Party System

different ways. Perhaps best known is the question that asks if respondents have a

favorable or unfavorable opinion of each party. Tables 1 (Democrats) and 2

(Republicans) include the distribution of responses, going back to $1997 .^{1}$

(Tables 1 and 2 about here)

There are several noteworthy findings. First, there is no question that public esteem for both parties has fallen since the mid-1990s. In the early years of the time series, the Democrats' favorability rating was at or just below 60 percent. In 2006, it dropped below 50 percent for the first time, and has remained below that mark since 2010. In 2012, for the first time, the Democrats' unfavorability rating was higher than its favorability score.

Perceptions of the Republicans followed a similar pattern. The party's favorability rating dropped quite dramatically over the years. In the late 1990s and early 2000s, Republican Party favorability generally stood above the 50 percent mark. In recent years, it has not come close to that. In 2013, only one-third of Americans said they had a favorable opinion of the Republican Party, and the percentage of those unfavorable exceeded those favorable by an overwhelming 25 points $(58-33)$. Although perceptions of both parties have deteriorated over time, the Republicans appear to have taken the brunt of growing public discontent.

The Republican Party has also consistently suffered from a lower favorability rating than the Democrats. This is true in all years, except 2002. In some years, this gap has been very large -- 22 points in January 2009, for example. That large Democratic

\footnotetext{
${ }^{1}$ The data in Tables 1 and 2 come from PEW. Both CBS and Gallup have asked the same party favorability question multiple times over these years, with very similar results.
} 
Gold

advantage no doubt reflected positive feeling surrounding the historic election of Barack Obama in November 2008. Other fluctuations over time similarly reflect major political developments. The one point at which the Republicans held an advantage was December 2002, shortly after the midterm elections and during the run-up to the Iraq war. But the Democrats' favorability advantage has generally ranged from about five to ten points.

The pattern of growing discontent with the parties appears on other questions as well. The American National Election Studies (ANES) have consistently asked respondents to rate the parties on a 100-degree feeling thermometer. Tables 3 , 4, and 5 present the percentage of respondents who express negative (below 50), neutral (50 degrees), and positive (above 50) ratings of each party, as well as their ratings of the "major parties" as an institution. For the Democrats, the percentage of people expressing a negative rating (37\%) was higher in 2012 than it has been at any time since $1996 .^{2}$ Similarly, negative affect toward the Republicans grew by 13 percentage points (32 to 45) between 1996 and 2012. And not surprisingly, we find growing negative assessments of the "major parties;" 19 percent were negative in 1996, a figure that jumped to 29 percent in 2008. In all three cases, growing negativity has been the consequence of fewer people with positive ratings; the proportion of neutral respondents has remained fairly stable.

(Tables 3, 4, and 5 about here)

ANES also has asked respondents if there is anything in particular they like or dislike about the Democratic and Republican parties. The most notable shift has occurred on the Democratic side (see Table 6). In 2012, for the first time, the percentage of

\footnotetext{
${ }^{2}$ Indeed it was higher in 2012 than it has been since 1978, when ANES first asked respondents to rate the parties on a feeling thermometer.
} 
Poll Trends-Americans' Attitudes toward the Political Parties and the Party System

individuals who express at least one dislike of the Democratic Party exceeds the percentage expressing a like. This marks a major change from prior years, where the ratio was consistently greater than one (see $3^{\text {rd }}$ column of Table 6). The Republicans have typically drawn more dislikes than likes, although that ratio was particularly unfavorable in 2008 (see Table 7).

(Tables 6 and 7 about here)

\section{Perceptions of Partisan Difference}

The evidence reviewed to this point indicates that Americans have grown increasingly negative toward both parties in recent years. One possible cause is heightened partisan polarization. To what extent do Americans view the parties as different from each other, and has that changed over time?

To answer these questions, I examine three survey items that ask respondents about their perceptions of partisan difference and ideology. The first one, from ANES, asks respondents if they perceive important differences in what the major parties stand for (see Table 8). The evidence here is decisive: We have seen a significant growth in the proportion of Americans who believe that there are major differences between the parties. In 1996, that figure was 64 percent, and by 2012, it had jumped to over 80 percent. It is apparent that, at a minimum, the public has recognized the growing elite-level polarization, and increasingly sees the parties as very different. Additional evidence supports this conclusion. The ANES also asks respondents where they place each party on a 7-point ideological spectrum (1=liberal; $7=$ conservative). Table 9 includes the mean placement of each party since 1996, along with the difference between the respective 
Gold

means. Not surprisingly, Republicans are consistently rated as more conservative than Democrats. But the size of this gap has grown, such that by 2012, it exceeded 2.5 points (on a 7-point scale) for the first time since ANES first asked this question in 1972. Interestingly, much of this change is the product of growing perceptions of the Democrats as liberal. Whereas the mean Republican placement has consistently been near the conservative end of the scale (above 5), the Democratic mean has been nearer to the midpoint of the scale (3.5), until 2012 (when it dropped to 2.66).

(Tables 8 and 9 about here)

Questions asked by commercial survey organizations also support this finding that the public has increasingly come to view the Democrats as liberal, indeed "too liberal." Since 2009, the proportion of Americans who perceive the Democratic Party as too liberal has been close to 50 percent, whereas in earlier years, it was at 40 percent or even below (see Table 10). This has been accompanied by a drop in the proportion of Americans who say that the Democrats' views are "about right." On the Republican side, there has been greater stability over time, with those who see the party as too conservative holding steady, at around 40 percent (see Table 11). By 2010, the proportion perceiving the Republicans as too conservative was 9 points lower than the proportion seeing the Democrats as too liberal. This is one advantage the Democrats appear to have lost - the perception that they are a more mainstream party.

(Tables 10 and 11 about here)

\section{Evaluations of the Party System}


Poll Trends-Americans' Attitudes toward the Political Parties and the Party System

In recent years, Americans have expressed more negativity toward both parties, and they have come to view the parties as more ideologically distinct. Have these patterns produced greater receptivity to possible changes in the party system, in particular the possibility of a new third party contesting national elections?

There have been various survey questions about the effectiveness of the two-party system. Regardless of the wording, strong support exists in recent years for more electoral choice. Since 1996, PEW (along with NYT/CBS and PSRA) has asked Americans if the country should have a third political party to compete with the Democrats and Republicans (see Table 12). In most years, a majority of Americans agree that we need a third party - generally 45-55 percent adopt this view. Likewise, large proportions (54-67\%) support the idea that third parties should run candidates for President, Congress, and state offices (see Table 13). Interestingly, in spite of growing negativity toward the major parties, there is still a sizable minority - generally in the 4050 percent range - that disagree with the statement that the country needs a third political party (see Table 12). Some of the variation observed in these tables may be the product of wording differences employed by the various survey organizations, but it appears that the public is open to the idea of a new national political party.

(Tables 12 and 13 about here)

Since 2003, Gallup has asked a related question: Do the major parties do an adequate job of representing the American people? Only once (in 2003) did a plurality defend the two major parties (see Table 14). Although the response patterns here have been volatile, in just about every other year more respondents have stated that a third 
Gold

major party is needed. In some years $(2013,2010,2007)$, about 60 percent of respondents have expressed this view.

(Table 14 about here)

Other survey organizations have asked similar questions, albeit less consistently. In the question asked by NBC/WSJ (see Table 15), only 12-15 percent state that the twoparty system works fairly well. Instead, over half the respondents acknowledge that there are real problems with it, and about a third of respondents believe it is so broken that the country needs a third party. In a variation of this question (see Table 16), over half of respondents surveyed in 2007 stated that the two-party system does not do a good job of addressing important issues, a large jump from when this question was first asked in 1999.

(Tables 15 and 16 about here)

Although there is deep discontent with the two-party system and support for greater electoral choice, in most elections, support for third parties is very weak. Yet when asked generically whether or not they would consider voting for a third-party candidate, sizable majorities say that they would (see Table 17). In eight polls conducted between 1999 and 2013, between 52 and 67 percent of respondents said they would consider voting for a third-party presidential candidate. Of course, stating that one will "consider" voting for a third party poses a low threshold. That becomes apparent when the stakes are raised and respondents are asked to specify how "likely" it is that they will vote, or consider voting, for a generic third-party candidate. Whereas 50-65 percent initially state that they will consider voting for a third party candidate, only about one- 
Poll Trends-Americans' Attitudes toward the Political Parties and the Party System

third of respondents state that it is "likely" that they will vote, or even consider voting, for a third party (see Table 18).

(Tables 17 and 18 about here)

Other questions have been asked over the years that shed more light on the public's ambivalence toward changing the two-party system. Unfortunately, these questions have not been asked consistently. Nevertheless, evidence exists showing sizable majorities believe that a third party would raise issues that the major parties do not address (58\%, CBS/NYT, March 1996); that voting for a third party candidate sends an important message that the political system needs to change (55\%, FOX, June 1999); and that it would be good for the country if a third-party candidate were to win the 2008 presidential election (45\% good, $19 \%$ bad; FOX, June 2007). At the same time, there is lingering doubt that American democracy would work any better with a viable third party. In 1996, a plurality of respondents expressed the view that the effectiveness of American democracy would not be enhanced by the creation of a third party $(46 \%$, National Survey on Democracy, January 1996). That same year, a majority (53\%) stated that a third party would not make much difference in producing better candidates (NYT/CBS, March 1996). In 2000, a majority (55\%) held that third parties end up hurting the election by taking votes away from the major parties (LAT, July 2000). And, on the one question that was replicated over time, strong majorities held that third parties would not make much difference in giving ordinary people more say in government. In 1996, 56 percent held that position; in 2010, 60 percent expressed that view (see Table 19).

(Table 19 about here) 
Gold

\section{Conclusion}

In his 1996 POQ Poll Trends article, Collet concluded that the American public expressed "extreme discontent" toward the party system, though not toward the two parties themselves, and that Americans supported the notion of a new national third party, but would not translate that hypothetical support into support for a particular third party. Almost twenty years later, we are still in a period of "extreme discontent," but this discontent now extends beyond the party system to the two major parties themselves; and the public is still conflicted between its attachment to the existing parties and a restructuring of the party system that would see the emergence of a new national third party. There is no question that public disdain for both the Democratic and Republican parties has grown considerably since the mid-1990s and that the public understands well the polarization that has gripped political elites. Increasing numbers of Americans have come to see the parties as ideologically far apart, with large percentages stating that the Republicans are too conservative and that the Democrats are too liberal. Paradoxically, although the public is turned off by ideological parties, there is also evidence that partisans have become more critical of their own party for not upholding traditional "liberal” and "conservative" values (PEW, January 2014).

Despite consistent majorities and pluralities who believe that the country needs a third political party and that the Democrats and Republicans inadequately represent the people, only a minority of Americans are likely to consider voting for a third-party candidate - this has remained fairly consistent over time. And there is plenty of ambivalence about the benefits of a third party for American democracy. Unfortunately, many of the questions that measure attitudes toward third parties and the party system are 
Poll Trends-Americans' Attitudes toward the Political Parties and the Party System

asked sporadically, and more commonly when a prominent third-party candidate (like

Perot) emerges. This not only creates an obvious context effect; it also hampers our ability to understand the public's long-term views of the party system. Still, the best evidence suggests that although the Democratic and Republican parties have become the object of deepening disapproval and even contempt, the American public is not quite ready to let go of them.

\section{Appendix}

\section{Abbreviations}

A, McH, and Assoc.: Ayres, McHenry and Associates

ANES: American National Election Studies

AP: Associated Press

CBS: Columbia Broadcasting System

CNN: Cable News Network

FOX: Fox News

LAT: Los Angeles Times

NBC: National Broadcasting Corporation

NYT: New York Times

PEW: Pew Research Center for the People \& the Press

ORC: Opinion Research Corporation

PSRA: Princeton Survey Research Associates

WP: Washington Post

WSJ: Wall Street Journal

USAT: USA Today

The survey results reported in this article were obtained from searches of the iPOLL Databank provided by the Roper Center for Public Opinion Research at the University of Connecticut (http://www.ropercenter.uconn.edu/) and from the American National Election Studies (http://www.electionstudies.org). Unless otherwise noted, all surveys were conducted by telephone interviews with national adult samples.

ANES (RR1): Data from ANES 1996 - 2012 pre- and post-election surveys. Mode of interview was face-to-face (FTF) for all years, except for a split mode design in 2000 (FTF and telephone subsample) and in 2012 (FTF and internet subsample). 1996 59.8\%; 1998 63.9\%; 2000 60.5\%; 2004 58.2\%; 2008 59.5\%; 2012 38\% (FTF) 2\% (Internet). 
Gold

AP/Yahoo (RR2): Conducted by Knowledge Networks. Online interviews. 12/07 $12.6 \% ; 1 / 0812.4 \%$.

CBS (RR1): 6/07 9.03\%.

FOX (RR3): 2011-2013 polls conducted by Anderson Robbins Research and Shaw and Company Research; polls prior to 2011 conducted by Opinion Dynamics. 6/99 7.5\%; 7/99 8\%; 6/06 5.7\%; 6/07 7.6\%; 7/10 6.8\%; 8/11 16.6\% (landline) 10.1\% (cellular); $10 / 138 \%$ (landline) $5.3 \%$ (cellular).

Gallup (RR3): 11/98 35\%; 2/99 20\%; 7/99 24\%; 11/02 (17\%); 10/03 16\%; 6/06 16\%; 9/06 16\%; 10/06 16\%; 9/07 13\%; 2/08 11\%; 9/08 15\%; 6/09 13\%; 5/10 8\%; 8/10 9\%; 4/11 8\%; 9/11 10\%; 9/12 11\%; 10/13 6\%.

NYT/CBS (RR1): 2/10 10.45\%; 4/10 9.53\%; 9/10 8.95\%.

PEW (RR3): 1/01 31\%; 10/03 27.3\%; 2/04 32.8\%; 6/04 30.3\%; 6/05 28.8\%; 2/06 22.2\%; 4/06 27.8\%; 7/07 16.7\%; 5/08 19.7\%; 6/08 21.8\% (landline) 23.3\% (cellular); 1/09 $20.4 \%$ (landline) $21.1 \%$ (cellular); $11 / 0918.5 \%$ (landline) $9.9 \%$ (cellular); $2 / 1021.5 \%$ (landline) $13.3 \%$ (cellular); 6/10 12.9\% (landline) 9.2\% (cellular); 2/11 13.5\% (landline) $6.6 \%$ (cellular); $1 / 1210.7 \%$ (landline) $6.4 \%$ (cellular); $6 / 1211.3 \%$ (landline) $5.6 \%$ (cellular); $1 / 1310.4 \%$ (landline) 5.9\% (cellular); 3/14 11.2\% (landline) $9.8 \%$ (cellular).

PSRA/Newsweek (RR3): 6/07 25.8\%; 10/07 24.7\%.

Response rates for other surveys were requested but not available. 
Poll Trends-Americans' Attitudes toward the Political Parties and the Party System

\section{References}

Abramowitz, Alan, and Kyle Saunders. 1998. "Ideological Realignment in the U.S.

Electorate." Journal of Politics 60:634-52.

Baumer, Donald, and Howard Gold. 2010. Parties, Polarization, and Democracy in the U.S. Boulder, CO: Paradigm.

Beck, Paul Allen. 1976. "A Socialization Theory of Partisan Realignment," in Controversies in American Voting Behavior, edited by Richard Niemi and Herbert Weisberg, 396-411. San Francisco: Freeman.

Campbell, Angus, Philip Converse, Warren Miller, and Donald Stokes. 1960. The American Voter. New York: Wiley.

Collet, Christian. 1996. "The Polls - Trends: Third Parties and the Two-Party System." Public Opinion Quarterly 60:431-49.

Fiorina, Morris, Samuel Abrams and Jeremy C. Pope. 2011. Culture War? The Myth of a Polarized America. New York: Pearson Longman.

Green, Donald, Bradley Palmquist, and Eric Schickler. 2002. Partisan Hearts and Minds: Political Parties and the Social Identities of Voters. New Haven: Yale University Press.

Hetherington, Marc. 2001. "Resurgent Mass Partisanship: The Role of Elite Polarization." American Political Science Review 95:619-639.

Nie, Norman, Sidney Verba, and John Petrocik. 1976. The Changing American Voter. Chicago: University of Chicago Press.

Polsby, Nelson. 1983. Consequences of Party Reform. New York: Oxford University Press. 
Gold

Saunders, Kyle, and Alan Abramowitz. 2004. "Ideological Realignment and Active Partisans in the American Electorate." American Politics Research 32:285-309.

Stonecash, Jeffrey, Mark Brewer, and Mack Mariani. 2003. Diverging Parties: Social Change, Realignment, and Party Polarization. Boulder, CO: Westview Press.

Wattenberg, Martin. 1998. The Decline of American Political Parties, 1952-1996, $5^{\text {th }}$ edition. Cambridge, MA: Harvard University Press. 
Poll Trends-Americans' Attitudes toward the Political Parties and the Party System

Table 1. Democratic Party Favorability

PEW: "Would you say your overall opinion of the Democratic Party is favorable or unfavorable?"

\begin{tabular}{|c|c|c|c|c|}
\hline Date & $\begin{array}{c}\text { Favorable } \\
(\%)\end{array}$ & $\begin{array}{c}\text { Unfavorable } \\
(\%)\end{array}$ & $\begin{array}{c}\text { Can't } \\
\text { rate/Don't } \\
\text { know } \\
(\%)\end{array}$ & $\mathrm{N}$ \\
\hline $3 / 14$ & 46 & 47 & 7 & 10,013 \\
\hline $1 / 13$ & 47 & 46 & 7 & 1,502 \\
\hline $1 / 12$ & 42 & 51 & 7 & 1,502 \\
\hline $2 / 11$ & 47 & 46 & 7 & 1,385 \\
\hline $2 / 10$ & 48 & 44 & 8 & 1,383 \\
\hline $1 / 09$ & 62 & 32 & 6 & 1,503 \\
\hline $5 / 08$ & 57 & 37 & 6 & 1,505 \\
\hline $7 / 07$ & 51 & 41 & 8 & 1,503 \\
\hline $2 / 06$ & 48 & 43 & 9 & 1,502 \\
\hline $6 / 05$ & 52 & 39 & 9 & 1,464 \\
\hline $2 / 04$ & 58 & 37 & 5 & 1,500 \\
\hline $12 / 02$ & 54 & 37 & 9 & 1,205 \\
\hline $1 / 01$ & 60 & 30 & 10 & 1,258 \\
\hline $1 / 99$ & 56 & 38 & 6 & 1,200 \\
\hline $3 / 98$ & 58 & 36 & 6 & 1,206 \\
\hline $1 / 97$ & 60 & 35 & 5 & 1,503 \\
\hline
\end{tabular}


Gold

Table 2. Republican Party Favorability

PEW: "Would you say your overall opinion of the Republican Party is favorable or unfavorable?"

\begin{tabular}{|l|c|c|c|c|}
\hline Date & $\begin{array}{c}\text { Favorable } \\
(\%)\end{array}$ & $\begin{array}{c}\text { Can't } \\
\text { Unfavorable } \\
(\%)\end{array}$ & $\begin{array}{c}\text { cate/Don't } \\
\text { know } \\
(\%)\end{array}$ & $\mathrm{N}$ \\
\hline $3 / 14$ & 37 & 55 & 7 & 10,013 \\
\hline $1 / 13$ & 33 & 58 & 9 & 1,502 \\
\hline $1 / 12$ & 35 & 58 & 7 & 1,502 \\
\hline $2 / 11$ & 43 & 48 & 9 & 1,385 \\
\hline $2 / 10$ & 46 & 46 & 8 & 1,383 \\
\hline $1 / 09$ & 40 & 55 & 5 & 1,503 \\
\hline $5 / 08$ & 39 & 53 & 8 & 1,505 \\
\hline $7 / 07$ & 39 & 53 & 8 & 1,503 \\
\hline $2 / 06$ & 44 & 49 & 7 & 1,502 \\
\hline $6 / 05$ & 48 & 44 & 8 & 1,464 \\
\hline $2 / 04$ & 52 & 42 & 6 & 1,500 \\
\hline $12 / 02$ & 59 & 34 & 7 & 1,205 \\
\hline $1 / 01$ & 56 & 34 & 10 & 1,258 \\
\hline $1 / 99$ & 44 & 50 & 6 & 1,200 \\
\hline $3 / 98$ & 50 & 43 & 7 & 1,206 \\
\hline $1 / 97$ & 52 & 43 & 5 & 1,503 \\
\hline
\end{tabular}




\section{Table 3. Feeling Thermometer Ratings of the Democratic Party}

ANES: "I'd like to get your feelings toward some of our political leaders and other people who are in the news these days. I'll read the name of a person and I'd like you to rate that person using something we call the feeling thermometer. Ratings between 50 degrees and 100 degrees mean that you feel favorable and warm toward the person. Ratings between 0 degrees and 50 degrees mean that you don't feel favorable toward the person and that you don't care too much for that person. You would rate the person at the 50 degree mark if you don't feel particularly warm or cold toward the person. How would you rate the DEMOCRATIC PARTY?"

\begin{tabular}{|l|c|c|c|c|}
\hline Date & $\begin{array}{c}\text { Negative } \\
(0-49 \text { degrees }) \\
(\%)\end{array}$ & $\begin{array}{c}\text { Neutral } \\
(50 \text { degrees }) \\
(\%)\end{array}$ & $\begin{array}{c}\text { Positive } \\
(51-100 \text { degrees }) \\
(\%)\end{array}$ & $\mathrm{N}$ \\
\hline 2012 & 37 & 15 & 48 & 5,856 \\
\hline 2008 & 21 & 17 & 52 & 2,259 \\
\hline 2004 & 27 & 16 & 57 & 1,178 \\
\hline 2000 & 26 & 18 & 56 & 1,748 \\
\hline 1998 & 25 & 16 & 60 & 1,253 \\
\hline 1996 & 27 & 13 & 60 & 1,685 \\
\hline
\end{tabular}


Gold

\section{Table 4. Feeling Thermometer Ratings of the Republican Party}

ANES: "I'd like to get your feelings toward some of our political leaders and other people who are in the news these days. I'll read the name of a person and I'd like you to rate that person using something we call the feeling thermometer. Ratings between 50 degrees and 100 degrees mean that you feel favorable and warm toward the person. Ratings between 0 degrees and 50 degrees mean that you don't feel favorable toward the person and that you don't care too much for that person. You would rate the person at the 50 degree mark if you don't feel particularly warm or cold toward the person. How would you rate the REPUBLICAN PARTY?"

\begin{tabular}{|l|c|c|c|c|}
\hline Date & $\begin{array}{c}\text { Negative } \\
(0-49 \text { degrees }) \\
(\%)\end{array}$ & $\begin{array}{c}\text { Neutral } \\
(50 \text { degrees }) \\
(\%)\end{array}$ & $\begin{array}{c}\text { (Positive) } \\
51-100 \text { degrees } \\
(\%)\end{array}$ & $\mathrm{N}$ \\
\hline 2012 & 45 & 17 & 38 & 5,855 \\
\hline 2008 & 44 & 21 & 35 & 2,252 \\
\hline 2004 & 33 & 18 & 49 & 1,176 \\
\hline 2000 & 31 & 20 & 49 & 1,741 \\
\hline 1998 & 38 & 18 & 44 & 1,245 \\
\hline 1996 & 32 & 17 & 51 & 1,677 \\
\hline
\end{tabular}




\section{Table 5. Feeling Thermometer Ratings of the Major Parties}

ANES: "I'd like to get your feelings toward some of our political leaders and other people who are in the news these days. I'll read the name of a person and I'd like you to rate that person using something we call the feeling thermometer. Ratings between 50 degrees and 100 degrees mean that you feel favorable and warm toward the person. Ratings between 0 degrees and 50 degrees mean that you don't feel favorable toward the person and that you don't care too much for that person. You would rate the person at the 50 degree mark if you don't feel particularly warm or cold toward the person. How would you rate the MAJOR PARTIES?"

\begin{tabular}{|l|c|c|c|c|}
\hline Date & $\begin{array}{c}\text { Negative } \\
(0-49 \text { degrees }) \\
(\%)\end{array}$ & $\begin{array}{c}\text { Neutral } \\
(50 \text { degrees }) \\
(\%)\end{array}$ & $\begin{array}{c}\text { Positive } \\
(51-100 \text { degrees }) \\
(\%)\end{array}$ & $\mathrm{N}$ \\
\hline 2008 & 29 & 23 & 48 & 2,322 \\
\hline 2004 & 24 & 23 & 52 & 1,172 \\
\hline 2000 & 20 & 23 & 57 & 1,731 \\
\hline 1998 & 25 & 24 & 51 & 1,242 \\
\hline 1996 & 19 & 25 & 56 & 1,675 \\
\hline
\end{tabular}


Gold

Table 6. Democratic Party Likes and Dislikes

ANES: "Is there anything in particular that you LIKE/DON'T LIKE about the Democratic Party?"

\begin{tabular}{|l|c|c|c|c|}
\hline Date & $\begin{array}{c}\text { Yes, Like } \\
\text { (\% of } \\
\text { respondents) }\end{array}$ & $\begin{array}{c}\text { Yes, Don't like } \\
\text { (\% of } \\
\text { respondents) }\end{array}$ & $\begin{array}{c}\text { Ratio of } \\
\text { Likes:Dislikes }\end{array}$ & $\begin{array}{c}\text { N } \\
\text { (Likes/Dislikes) }\end{array}$ \\
\hline 2012 & 48 & 49 & $1: 1.02$ & $5,797 / 5,797$ \\
\hline 2008 & 62 & 42 & $1: 0.68$ & $2,242 / 2,245$ \\
\hline 2004 & 57 & 48 & $1: 0.84$ & $1,181 / 1,185$ \\
\hline 2000 & 57 & 44 & $1: 0.77$ & $1,784 / 1,778$ \\
\hline 1996 & 52 & 45 & $1: 0.88$ & $827 / 825$ \\
\hline
\end{tabular}


Poll Trends-Americans' Attitudes toward the Political Parties and the Party System

\section{Table 7. Republican Party Likes and Dislikes}

ANES: "Is there anything in particular that you LIKE/DON'T LIKE about the Republican Party?"

\begin{tabular}{|l|c|c|c|c|}
\hline & $\begin{array}{c}\text { Yes, Like } \\
\text { (\% of } \\
\text { respondents) }\end{array}$ & $\begin{array}{c}\text { Yes, Don't like } \\
\text { (\% of } \\
\text { respondents) }\end{array}$ & $\begin{array}{c}\text { Ratio of } \\
\text { Likes:Dislikes }\end{array}$ & $\begin{array}{c}\mathrm{N} \\
\text { (Likes/Dislikes) }\end{array}$ \\
\hline 2012 & 43 & 55 & $1: 1.28$ & $5,793 / 5,789$ \\
\hline 2008 & 38 & 56 & $1: 1.47$ & $2,230 / 2,237$ \\
\hline 2004 & 48 & 55 & $1: 1.15$ & $1,188 / 1,184$ \\
\hline 2000 & 45 & 51 & $1: 1.13$ & $1,783 / 1,782$ \\
\hline 1996 & 43 & 51 & $1: 1.19$ & $831 / 825$ \\
\hline
\end{tabular}


Gold

Table 8. Differences between the Major Parties

ANES: "Do you think there are any important differences in what the Republicans and Democrats stand for?"

\begin{tabular}{|l|c|c|c|c|}
\hline Date & $\begin{array}{c}\text { Yes, important } \\
\text { differences } \\
(\%)\end{array}$ & $\begin{array}{c}\text { No important } \\
\text { differences } \\
(\%)\end{array}$ & $\begin{array}{c}\text { Don't } \\
\text { know } \\
(\%)\end{array}$ & $\mathrm{N}$ \\
\hline 2012 & 81 & 19 & 1 & 5,469 \\
\hline 2008 & 75 & 23 & 2 & 2,096 \\
\hline 2004 & 78 & 19 & 4 & 1,064 \\
\hline 2000 & 67 & 31 & 2 & 1,554 \\
\hline 1998 & 58 & 40 & 3 & 1,278 \\
\hline 1996 & 64 & 34 & 1 & 745 \\
\hline
\end{tabular}


Table 9. Placement of the Major Parties on the 7-Point Liberal-Conservative Scale

ANES: "We hear a lot of talk these days about liberals and conservatives. Here is a seven-point scale on which the political views that people might hold are arranged from extremely liberal to extremely conservative. Where would you place the DEMOCRATIC/REPUBLICAN PARTY on this scale?" 1 =most liberal; $7=$ most conservative).

\begin{tabular}{|l|c|c|c|}
\hline Date & $\begin{array}{c}\text { Mean placement } \\
\text { of Republican } \\
\text { Party } \\
(\mathrm{N})\end{array}$ & $\begin{array}{c}\text { Mean placement } \\
\text { of Democratic } \\
\text { Party } \\
(\mathrm{N})\end{array}$ & $\begin{array}{c}\text { Difference between } \\
\text { mean placements of } \\
\text { parties }\end{array}$ \\
\hline 2012 & $5.29(5,672)$ & $2.66(5,684)$ & 2.63 \\
\hline 2008 & $4.95(2,110)$ & $3.31(2,127)$ & 1.64 \\
\hline 2004 & $5.16(1,091)$ & $3.04(1,097)$ & 2.12 \\
\hline 2000 & $5.17(1,354)$ & $2.95(1,370)$ & 2.22 \\
\hline 1998 & $5.01(1,122)$ & $3.34(1,142)$ & 1.67 \\
\hline 1996 & $5.08(1,555)$ & $3.19(1,566)$ & 1.89 \\
\hline
\end{tabular}


Gold

Table 10. Perceptions of Democrats' Ideology

Gallup: "In general, do you think the political views of the Democratic Party are too conservative, too liberal, or about right?"

\begin{tabular}{|l|c|c|c|c|c|}
\hline Date & $\begin{array}{c}\text { Too } \\
\text { conservative } \\
(\%)\end{array}$ & $\begin{array}{c}\text { Too } \\
\text { liberal } \\
(\%)\end{array}$ & $\begin{array}{c}\text { About right } \\
(\%)\end{array}$ & $\begin{array}{c}\text { No opinion } \\
(\%)\end{array}$ & $\mathrm{N}$ \\
\hline $5 / 10$ & 10 & 49 & 38 & 3 & 1,046 \\
\hline $6 / 09$ & 8 & 46 & 42 & 4 & 1,011 \\
\hline $2 / 08$ & 8 & 39 & 50 & 3 & 1,016 \\
\hline $10 / 6$ & 9 & 41 & 44 & 6 & 1,002 \\
\hline $11 / 02$ & 11 & 39 & 45 & 5 & 1,014 \\
\hline $2 / 99$ & 6 & 36 & 55 & 3 & 1,034 \\
\hline $11 / 98$ & 6 & 37 & 50 & 4 & 1,039 \\
\hline $10 / 96$ & 7 & 40 & 49 & 4 & 1,229 \\
\hline
\end{tabular}


Poll Trends-Americans' Attitudes toward the Political Parties and the Party System

\section{Table 11. Perceptions of Republicans' Ideology}

Gallup: "In general, do you think the political views of the Republican Party are too conservative, too liberal, or about right?"

\begin{tabular}{|l|c|c|c|c|c|}
\hline Date & $\begin{array}{c}\text { Too } \\
\text { conservative } \\
(\%)\end{array}$ & $\begin{array}{c}\text { Too } \\
\text { liberal } \\
(\%)\end{array}$ & $\begin{array}{c}\text { About right } \\
(\%)\end{array}$ & $\begin{array}{c}\text { No opinion } \\
(\%)\end{array}$ & $\mathrm{N}$ \\
\hline $5 / 10$ & 40 & 15 & 41 & 4 & 1,049 \\
\hline $6 / 09$ & 43 & 17 & 34 & 6 & 1,011 \\
\hline $2 / 08$ & 43 & 15 & 38 & 4 & 1,016 \\
\hline $10 / 6$ & 42 & 14 & 38 & 6 & 1,002 \\
\hline $11 / 02$ & 34 & 10 & 51 & 5 & 1,014 \\
\hline $2 / 99$ & 39 & 12 & 45 & 4 & 1,034 \\
\hline $11 / 98$ & 39 & 15 & 41 & 5 & 1,039 \\
\hline $10 / 96$ & 41 & 13 & 41 & 5 & 1,229 \\
\hline
\end{tabular}


Gold

\section{Table 12. Do We Need a Third Major Political Party?}

PEW, PSRA/Newsweek: "Some people say we should have a third major (political) party in this country in addition to the Democrats and Republicans. Do you agree or disagree?"

NYT/CBS: "Some people say the country needs a third political party - a new party to compete with the Democratic and Republican parties. Do you agree or disagree?"

\begin{tabular}{|c|c|c|c|c|}
\hline Date & $\begin{array}{c}\text { Agree } \\
(\%)\end{array}$ & $\begin{array}{c}\text { Disagree } \\
(\%)\end{array}$ & $\begin{array}{c}\text { Don't know/ } \\
\text { Refused } \\
(\%)\end{array}$ & $\mathrm{N}$ \\
\hline 6/12 (PEW) & 57 & 39 & 5 & 2,013 \\
\hline 9/10 (NYT/CBS) & 54 & 42 & 4 & 990 \\
\hline 4/10 (NYT/CBS) & 46 & 48 & 6 & 1,580 \\
\hline 6/10 (PEW) & 53 & 40 & 7 & 1,802 \\
\hline $2 / 10$ (NYT/CBS) & 42 & 53 & 5 & 1,125 \\
\hline 10/09 (PEW) & 52 & 40 & 8 & 2,000 \\
\hline 6/08 (PEW & 56 & 38 & 6 & 2,004 \\
\hline 10/07 (PSRA/Newsweek) & 54 & 39 & 7 & 1,185 \\
\hline 6/07 (PSRA/Newsweek) & 57 & 36 & 7 & 1,001 \\
\hline $6 / 07$ (CBS) & 53 & 41 & 6 & 836 \\
\hline 4/06 (PEW) & 53 & 40 & 7 & 1,501 \\
\hline 6/04 (PEW) & 50 & 43 & 7 & 1,806 \\
\hline 10/03 (PEW) & 46 & 44 & 10 & 1,515 \\
\hline 6/00 (PEW) & 52 & 42 & 6 & 2,174 \\
\hline 7/99 (PEW) & 54 & 40 & 6 & 3,973 \\
\hline 8/98 (PEW) & 46 & 47 & 7 & 2,266 \\
\hline 8/97 (PEW) & 47 & 46 & 7 & 1,213 \\
\hline 7/96 (PEW & 58 & 37 & 5 & 1,216 \\
\hline $3 / 96$ (NYT/CBS) & 53 & 42 & 5 & 1,257 \\
\hline
\end{tabular}




\section{Table 13. Should Third Parties Run Candidates?}

CNN/ORC, Gallup/CNN/USAT: "Would you favor or oppose having a third political party that would run candidates for President, Congress, and state offices against the Republican and Democratic candidates?"

FOX: "In general, do you think it would be a good idea or bad idea if a third national political party were formed that would run candidates for President, Congress, and state offices against the Republican and Democratic candidates?"

\begin{tabular}{|l|c|c|c|r|}
\hline Date & $\begin{array}{c}\text { Favor/ } \\
\text { Good idea } \\
(\%)\end{array}$ & $\begin{array}{c}\text { Oppose/ } \\
\text { Bad idea } \\
(\%)\end{array}$ & $\begin{array}{c}\text { Don't know/ } \\
\text { No opinion } \\
(\%)\end{array}$ & \multicolumn{1}{c|}{$\mathrm{N}$} \\
\hline $7 / 10($ FOX) & 57 & 30 & 10 & 900 \\
\hline $2 / 10(\mathrm{CNN} /$ ORC) & 64 & 34 & 2 & 1,023 \\
\hline $6 / 06(\mathrm{FOX})$ & 50 & 37 & 13 & 900 \\
\hline $7 / 99(\mathrm{Gallup} / \mathrm{CNN} /$ USAT) & 67 & 28 & 5 & 1,031 \\
\hline $7 / 99(\mathrm{FOX})$ & 57 & 31 & 12 & 898 \\
\hline $6 / 99($ FOX $)$ & 54 & 32 & 14 & 908 \\
\hline
\end{tabular}


Gold

Table 14. Do Major Parties Adequately Represent the American People?

Gallup, Gallup/CNN/USAT 1: "In your view, do the Republican and Democratic parties do an adequate job (of) representing the American people, or do they do such a poor job that a third major party is needed?"

Gallup/USAT 2: "In your view, do the Republican and Democratic parties do an adequate job of representing the American people, or would you like there to be a third major party as well?"

NYT/CBS: "In your view, do the Republican and Democratic parties do an adequate job of representing the American people, or do they not do an adequate job and a third major party is needed?"

\begin{tabular}{|l|c|c|c|c|}
\hline & $\begin{array}{c}\text { Major parties } \\
\text { do adequate } \\
\text { job } \\
(\%)\end{array}$ & $\begin{array}{c}\text { Third party } \\
\text { is needed } \\
(\%)\end{array}$ & $\begin{array}{c}\text { No opinion/ } \\
\text { Don't know } \\
(\%)\end{array}$ & N \\
\hline $10 / 13$ (Gallup) & 26 & 60 & 14 & 1,028 \\
\hline $9 / 12$ (Gallup) & 45 & 46 & 9 & 1,017 \\
\hline $12 / 11$ (Gallup/USAT 1) & 32 & 54 & 10 & 1,034 \\
\hline $9 / 11$ (Gallup) & 38 & 55 & 8 & 1,017 \\
\hline $4 / 11$ (Gallup/USAT 1) & 40 & 52 & 8 & 1,013 \\
\hline $8 / 10$ (Gallup/USAT 1) & 35 & 58 & 7 & 1,021 \\
\hline $2 / 10$ (NYT/CBS) & 27 & 59 & 14 & 1,125 \\
\hline $9 / 08$ (Gallup) & 47 & 47 & 6 & 1,007 \\
\hline $9 / 07$ (Gallup) & 39 & 57 & 4 & 1,010 \\
\hline $7 / 07$ (Gallup/USAT 1) & 33 & 58 & 10 & 1,014 \\
\hline $9 / 06$ (Gallup) & 45 & 48 & 7 & 1,002 \\
\hline $6 / 06$ (Gallup/USAT 2) & 40 & 54 & 3 & 1,000 \\
\hline $10 / 03$ (Gallup/CNN/USAT) & 56 & 40 & 4 & 1,004 \\
\hline
\end{tabular}




\section{Table 15. Is the Two-Party System Broken?}

NBC/WSJ: "Which of the following statements is closest to your own view of the two-party system today, in terms of how well it defines issues and provides choices for voters? The two-party system works fairly well. The two-party system has real problems, but with some improvements it can still work well. The two-party system is seriously broken, and the country needs a third party."

\begin{tabular}{|l|c|c|c|c|c|}
\hline Date & $\begin{array}{c}\text { Works fairly } \\
\text { well } \\
(\%)\end{array}$ & $\begin{array}{c}\text { Has real } \\
\text { problems, but can } \\
\text { still work well } \\
(\%)\end{array}$ & $\begin{array}{c}\text { Seriously } \\
\text { broken, need } \\
\text { third party } \\
(\%)\end{array}$ & $\begin{array}{c}\text { Don't know/ } \\
\text { Not sure } \\
(\%)\end{array}$ & $\mathrm{N}$ \\
\hline $12 / 11$ & 12 & 51 & 34 & 3 & 1,000 \\
\hline $8 / 11$ & 13 & 52 & 34 & 1 & 1,000 \\
\hline $5 / 10$ & 15 & 52 & 31 & 2 & 1,000 \\
\hline $12 / 97$ & 15 & 55 & 27 & 3 & 2,013 \\
\hline
\end{tabular}


Gold

Table 16. Does the Two-Party System Address Important Issues?

"In general, do you think the two-party system does a pretty good job of addressing issues that are most important to people like you, or not?"

\begin{tabular}{|l|c|c|c|c|}
\hline Date & $\begin{array}{c}\text { Yes, pretty } \\
\text { good job } \\
(\%)\end{array}$ & $\begin{array}{c}\text { No, not a } \\
\text { good job } \\
(\%)\end{array}$ & $\begin{array}{c}\text { Don't know } \\
(\%)\end{array}$ & N \\
\hline $6 / 07$ (PSRA/Newsweek) & 37 & 57 & 6 & 1,001 \\
\hline $5 / 07$ (WP/Kaiser) & 45 & 53 & 2 & 2,140 \\
\hline $10 / 99$ (PSRA/Newsweek) & 54 & 39 & 7 & 400 \\
\hline
\end{tabular}




\section{Table 17. Consider Voting for Third Party Candidate}

FOX 1: "In the next election, would you consider voting for a third party presidential candidate?"

FOX 2: "Would you consider voting for a presidential candidate you like who is a third party candidate?"

Reason-Rupe: "Would you consider voting for an independent or third party candidate for president in 2012?"

Democracy Corps (Greenberg Quinlan Rosner Research): "Please tell me whether the first statement or the second statement comes closer to your own view, even if neither is exactly right. First statement: I would consider voting for a third party candidate in next year's (2012) presidential election. Second statement: I would not consider voting for a third party candidate in next year's presidential election. Harris: "Thinking of the presidential election next year (2008), would you consider voting for an Independent candidate who is not a Democrat or Republican?" Ayres, McHenry and Associates (Party Control of Congress and Third Parties Survey): "There has been a lot of discussion lately about the possibility of third party candidates running for President (in 2000). Would you consider voting for a third party candidate for President, rather than either the Democratic or Republican nominees?"

\begin{tabular}{|l|c|c|c|c|r|}
\hline Date & $\begin{array}{c}\text { Yes/Consider } \\
(\%)\end{array}$ & $\begin{array}{c}\text { No/Not } \\
\text { consider } \\
(\%)\end{array}$ & $\begin{array}{c}\text { Maybe/ } \\
\text { Possibly } \\
(\%)\end{array}$ & $\begin{array}{c}\text { Don't } \\
\text { know } \\
(\%)\end{array}$ & $\mathrm{N}$ \\
\hline $10 / 13$ (FOX 1) & 64 & 30 & NA & 6 & 1,010 \\
\hline $8 / 11$ (FOX 2) & 66 & 27 & NA & 7 & 904 \\
\hline $8 / 11$ (Reason-Rupe) & 53 & 25 & 19 & 4 & 1,200 \\
\hline (8/11 Democracy Corps) & 53 & 42 & NA & 4 & 1,000 \\
\hline $3 / 11$ (Reason-Rupe) & 60 & 17 & 20 & 2 & 1,200 \\
\hline $7 / 07$ (Harris) & 66 & 30 & NA & 3 & 1,010 \\
\hline $6 / 07$ (FOX 2) & 67 & 25 & NA & 8 & 900 \\
\hline $9 / 99$ (A, McH, and Assoc.) & 52 & 37 & NA & 11 & 1,000 \\
\hline
\end{tabular}

Note.-NA, not applicable. 


\section{Table 18. Likelihood of Voting for a Third Party Candidate.}

AP/Yahoo, LAT 1: Regardless of how you plan to vote in this particular election $(2000,2008)$, how likely would you be to consider voting for a third party candidate? Likely, not likely.

LAT 2: Some people think it's a good idea to vote for third-party or independent candidates while others think that's a waste of one's vote. Will you consider voting for an independent or third-party candidate for president in 1996, or will you most likely decide between the nominees of the Democratic and Republican parties? (If would consider independent/third party, ask:) Will you be very likely or somewhat likely to vote for an independent or third-party candidate for president?

\begin{tabular}{|l|c|c|c|c|}
\hline Date & $\begin{array}{c}\text { Likely (very or } \\
\text { somewhat) } \\
(\%)\end{array}$ & $\begin{array}{c}\text { Not Likely/Would } \\
\text { likely choose } \\
\text { Dem or Rep } \\
(\%)\end{array}$ & $\begin{array}{c}\text { Refused/Not } \\
\text { answered } \\
(\%)\end{array}$ & N \\
\hline $1 / 08$ (AP/Yahoo) & 33 & 66 & 1 & 2,016 \\
\hline $12 / 07$ (AP/Yahoo) & 32 & 68 & NA & 1,821 \\
\hline $7 / 00$ (LAT 1) & 37 & 61 & 2 & 1,058 \\
\hline $04 / 96$ (LAT 2) & 31 & 57 & 12 & 1,374 \\
\hline
\end{tabular}

Note.-NA, not applicable. 
Poll Trends-Americans' Attitudes toward the Political Parties and the Party System

\section{Table 19. Will a Third Party Give People More Say?}

NYT/CBS: "If a third political party were created, do you think that would give people like you more say in the government, or wouldn't a third party make that much difference?"

\begin{tabular}{|l|c|c|c|c|c|}
\hline Date & $\begin{array}{c}\text { More say } \\
(\%)\end{array}$ & $\begin{array}{c}\text { Wouldn't make } \\
\text { much difference } \\
(\%)\end{array}$ & $\begin{array}{c}\text { Depends } \\
\text { (vol.) } \\
(\%)\end{array}$ & $\begin{array}{c}\text { Don't know } \\
(\%)\end{array}$ & $\mathrm{N}$ \\
\hline $2 / 10$ & 31 & 60 & 4 & 4 & 1,084 \\
\hline $3 / 96$ & 36 & 56 & 5 & 3 & 1,257 \\
\hline
\end{tabular}

